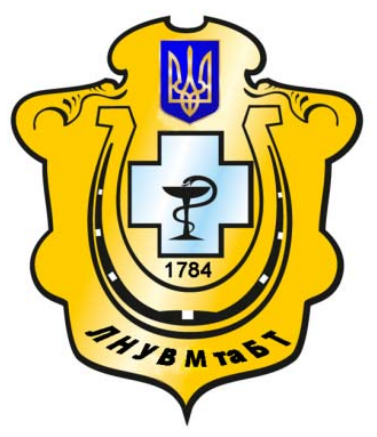

Науковий вісник Львівського національного університету ветеринарної медицини та біотехнологій імені С.3. Гжицького

Scientific Messenger of Lviv National University of Veterinary Medicine and Biotechnologies named after S.Z. Gzhytskyj

doi:10.15421/nvlvet7731

ISSN 2518-7554 print

ISSN 2518-1327 online

$\underline{\text { http://nvlvet.com.ua/ }}$

УДК 616.65-002- 007.61:616.832.9-008.8-078

\title{
Порівняльна оцінка ефективності препаратів «Сарофлокс» та енрофлоксацину відносно збудників бактеріозів птиці
}

\author{
T.I. Фотіна, С.В. Ващик \\ tif_ua@meta.ua, yevgeniavashik@gmail.com \\ Сумський національний аграрний університет, \\ вул. Герасима Кондратьєва, 160, м. Суми, 40000, Украӥна
}

\begin{abstract}
Розвиток у мікроорганізмів стійкості є основним чинником, щзо обмежує ефективність антимікробних препаратів $i$ тим самим стимулює розробку нових засобів або сполук. У зв'язку з иим метою роботи було провести порівняльну оцінку експериментального препарату «Сарофлокс» та енрофлоксацину відносно бактеріальної флори, щяо найчастіше виділяється від птиці та з патматеріалу птахогосподарств України. Чутливість досліджуваних культур мікроорганізмів до «Сарофлоксу» та енрофлоксачину визначали методом серійних розведень в рідкому пожсивному середовищі. В результаті досліджень встановлено, щь препарат «Сарофлокс» є ефективним відносно до основних збудників бактеріозів птиці. Бактерицидна активність препарату «Сарофлокс» є вищою в 2-4 рази порівняно з енрофлоксацином. Для більшості бактеріа-

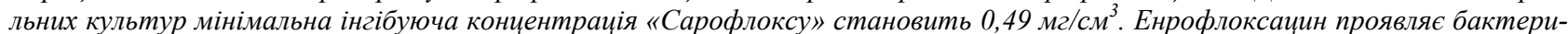

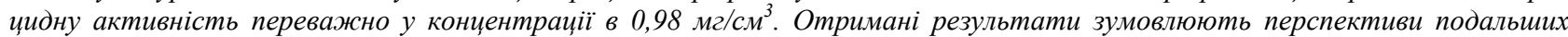
досліджень: вивчення активності засобу «Сарофлокс» порівняно з класичними препаратами в умовах птахівничих господарств Украӥни.

Ключові слова: бактерицидна активність, «Сарофлокс», енрофлоксацин, бактеріози птиці, антибіотикорезистентність, сальмонельоз, колібактеріоз.
\end{abstract}

\section{Сравнительная оценка эффективности препаратов «Сарофлокс» и энрофлоксацина относительно возбудителей бактериозов птицы}

\author{
Т.И. Фотина, Е.В. Ващик \\ tif_ua@meta.ua, yevgeniavashik@gmail.com \\ Сумский национальный аграрный университет, \\ ул. Герасима Кондратьева, 160, м. Суми, 40000, Украина
}

\begin{abstract}
Развитие у микроорганизмов устойчивости является основным фактором, ограничивающим эффективность антимикробных препаратов и стимулирующим разработку новых средств или соединений. В связи с этим целью работы было провести сравнительную оченку экспериментального препарата «Сарофлокс» и энрофлоксачина относительно бактериальной флоры, которая чаще всего выделяется от птиць и патматериала птицеводческих хозяйств Украины. Чувствительность исследуемых культур микроорганизмов к «Сарофлоксу» и энрофлоксацину определяли методом серийных разведений в жидкой питательной среде. В результате установлено, что препарат "Сарофлокс» является эффективным по отношению к основным возбудителям бактериозов птицы. Бактерицидная активность препарата «Сарофлокс» выше в $2-$ 4 раза по сравнению с энрофлоксацином. Для большинства бактериальных культур минимальная ингибирующая концентрация «Сарофлокса» составляет 0,49 мг/см . Энрофлоксаџин проявляет бактерицидную активность преимущественно в концентрации в $0,98 \mathrm{mz} / \mathrm{cm}^{3}$. Полученные результаты обуславливают перспективы дальнейших исследований: изучение активности препарата «Сарофлокс» по сравнению с классическими препаратами в условиях птицеводческих хозяйств Украинье
\end{abstract}

Citation:

Fotina, T.I., Vashchyk, Ye.V. (2017). Comparative evaluation of effectiveness of preparations «Saroflox» and enrofloxacin towards to the pathogens of poultry's bacterial diseases. Scientific Messenger LNUVMBT named after S.Z. Gzhytskyj, 19(77), 143-147. 
Ключевые слова: бактерицидная активность, «Сарофлокс», энрофлоксачин, бактериозы птицы, антибиотикорезистентность, сальмонеллез, колибактериоз.

\title{
Comparative evaluation of effectiveness of preparations «Saroflox» and enrofloxacin towards to the pathogens of poultry's bacterial diseases
}

\author{
T.I. Fotina, Ye.V. Vashchyk \\ tif_ua@meta.ua, yevgeniavashik@gmail.com \\ Sumy National Agrarian University, \\ Gerasim Kondratyev Str., 160, Sumy, 40000, Ukraine
}

\begin{abstract}
A serious problem of modern industrial poultry farming is a bacterial infection of birds. The fight against bacterial pathology includes a complex veterinary and sanitary measures, including an important element is the use of chemotherapeutic agents. The development of resistance in microorganisms is the main factor limiting the effectiveness of antibiotics and stimulating the elaboration of new preparations or compounds.

In this regard, the aim of the work was to make a comparative evaluation of the experimental preparation «Saroflox» and enrofloxacin towards to the bacterial flora, which is most often isolated from poultry and pathological material of poultry farms in Ukraine. The sensitivity of the bacterial cultures to «Saroflox» and enrofloxacin was determined by serial dilutions method in liquid nutrient medium - meat - peptone broth. In experiments have used bacterial cultures that have been isolated in poultry farms in Ukraine: S. aureus, S. fecalis, S. pullorum, S. typhimurium, S. enteritidis, E. coli O78, E. coli O2, P. vulgaris, P. aeruginosa, K. pneumoniae, C. perfringens, Y. enterocolitica, C. jejuni, C. diversus, E. agglomerans. Preparations Sarofloks and enrofloxacin are antibiotic fluoroquinolones group.

As a result, it is established that the preparation «Saroflox» is effective against the main pathogens of bacteriosis of the bird. The bactericidal activity of the "Saroflox» is 2-4 times higher than that of enrofloxacin. For most bacterial cultures, the minimum inhibitory concentration of "Saroflox》 is $0.49 \mathrm{mg} / \mathrm{cm}^{3}$. Thus, the results of our research indicate that the preparation «Sarofloks» may be the subject of choice for the bird associated infections because of higher activity compared to the control drug of enrofloxacin for example. The obtained results determine the prospects for further research: the study of the activity of the "Saroflox» in comparison with classical drugs in poultry farming in Ukraine.
\end{abstract}

Key words: bactericidal activity, "Saroflox», enrofloxacin, bacteriosis of birds, antibiotic resistance, salmonelosis, colibacteriosis.

\section{ВстуII}

Серйозною проблемою сучасного промислового птахівництва $є$ бактеріальні інфекції птахів. Незважаючи на досягнуті успіхи у боротьбі та профілактиці, бактеріальні інфекції продовжують становити серйозну загрозу епізоотичному благополуччю птахівничої галузі.

Серед бактеріальних інфекцій найбільш значних втрат птахівництву завдають такі захворювання: колібактеріоз, сальмонельоз, стрептококоз, стафілококоз, респіраторний мікоплазмоз, псевдомоноз. Економічні втрати обумовлюються зниженням несучості та приростів, загибеллю ембріонів, курчат та дорослої птиці (Pavlov et al., 2003; Fotina, 2013).

Боротьба з бактеріальної патологією включає в себе комплекс ветеринарно-санітарних заходів, серед яких важливим елементом є використання хіміотерапевтичних препаратів. Однак у зв'язку з розвитком антибіотикорезистентності до препаратів гостро стоїть проблема пошуку нових шляхів запобігання формуванню стійкості та впливу на резистентних мікроорганізмів (Fotina et al., 2003).

Розвиток у мікроорганізмів стійкості є основним чинником, що обмежує ефективність антимікробних препаратів і стимулює розробку нових засобів або сполук.

Мета і завдання дослідження. У зв'язку з цим метою нашої роботи було провести порівняльну оцінку експериментального препарату «Сарофлокс» та енрофлоксацину відносно бактеріальної флори, що найча- стіше виділяється від птиці та з патматеріалу птахогосподарств України. Для реалізації обраної мети було поставлено завдання:

- встановити ефективність експериментального препарату «Сарофлокс» та енрофлоксацину щодо збудників бактеріальних інфекцій птиці, які було виділено з птахівничих господарств;

- провести порівняльну оцінку даних препаратів.

\section{Матеріал і методи дослідження}

Дослідження були проведені в лабораторії кафедри ветсанекспертизи, мікробіології, зоогігієни та безпеки і якості продуктів тваринництва факультету ветеринарної медицини Сумського національного аграрного університету.

В досліді використовували культури мікроорганізмів, що були ізольовані в птахівничих господарствах України: $S$. aureus, $S$. fecalis, $S$. pullorum, S. typhimurium, S. enteritidis, E. coli O78, E. coli O2, $P$. vulgaris, $P$. aeruginosa, $K$. pneumoniae, C. perfringens, $Y$. enterocolitica, C. jejuni, C. diversus, E. agglomerans.

Чутливість досліджуваних культур мікроорганізмів до «Сарофлоксу» та енрофлоксацину визначали методом серійних розведень в рідкому поживному середовищі - м'ясопептонному бульйоні (МПБ).

Для досліджень попередньо розливали в пробірки по 0,5 мл МПБ. В першу пробірку вносили 0,5 мл робочого розчину препарату, ретельно перемішували, відбирали 0,5 мл суміші та переносили в наступну 
пробірку. Процедуру повторювали до передостанньої пробірки включно. Останню пробірку з МПБ залишали без внесення розчину препарату для негативного контролю, 3 неї 0,5 мл бульйону видаляли. Таким чином, отримували ряд пробірок 3 двократними розведеннями антибіотиків. У всі пробірки вносили по 0,5 мл зависі тест-культур. Для інокуляції використовували мікробну суспензію, еквівалентну 0,5 за стандартом Мак Фарланда, розведену в 100 разів у рідкому поживному середовищі. Інкубацію проводили 24 год при $+37^{\circ} \mathrm{C}$. Контрольну пробірку витримували в холодильнику при $+4{ }^{\circ} \mathrm{C}$ та використовували для порівняння. Облік результатів проводили візуально за наявністю або відсутністю росту культур у світлі, що проходить, порівняно 3 контролем (Opredeleniye chuvstvitel'nosti mikroorganizmov $\mathrm{k}$ antibakterial'nymi preparatami, 2004).

Препарат «Сарофлокс» відноситься до антибіотиків групи фторхінолонів. Механізм його бактерицидної дії зумовлений гальмуванням активності ДНК-гіраз, які забезпечують реплікацію ДНК в ядрах мікробних клітин та їх подальший поділ. В результаті пригнічується розмноження мікроорганізмів. Енрофлоксацин $\epsilon$ широко вживаним антибіотиком групи фторхінолонів.

Мінімальною інгібуючою концентрацією (МІК) досліджуваного препарату щодо обраних культур бактерій вважали концентрацію, яка викликала повну інгібіцію (прозорий бульйон) видимого росту, що визначало ступінь їх чутливості до препарату в певному співвідношенні та розведенні.

\section{Результати та їх обговорення}

В результаті визначення ефективності $10 \%$ препарату «Сарофлокс» встановлено, що мінімальна інгібуюча концентрація для більшості досліджуваних

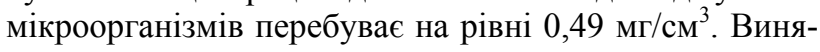
тком були культури сероварів ( $S$. aureus, S. fecalis, S. pullorum, S. enteritidis), для яких мінімальна інгібуюча концентрація 10\% препарату «Сарофлокс» становила $0,24 \mathrm{мг} / \mathrm{cm}^{3}$ (табл. 1).

Таким чином, встановлено, що до препарату 10\% «Сарофлокс» була чутлива вся ізольована мікрофлоpa.

В порівняльному аспекті були проведені дослідження з 10\% енрофлоксацином.

Встановлено, що мінімальна інгібуюча концентрація препарату для більшості досліджуваних мікроор-

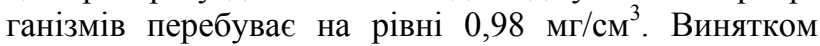
були культури сероварів (S. pullorum, E. coli O2, Y. enterocolitica), для яких мінімальна інгібуюча концентрація $10 \%$ препарату енрофлоксацин становила $0,49 \mathrm{мг} / \mathrm{cm}^{3}$ (табл. 2).

При проведенні порівняльної оцінки активності «Сарофлоксу» та енрофлоксацину визначено, що ефективність «Сарофлоксу» $є$ вищою: для більшості бактеріальних культур мінімальна інгібуюча концент-

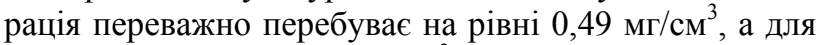
енрофлоксацину $-0,98$ мг/ $\mathrm{cm}^{3}$ (табл. 3).

Результати визначення мінімальної інгібуючої концентрації препарату 10\% «Сарофлокс»

\begin{tabular}{|c|c|c|c|c|c|c|c|c|c|c|c|c|c|c|c|c|c|c|c|}
\hline \multirow[b]{3}{*}{ 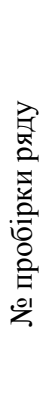 } & \multicolumn{18}{|c|}{ Метод серійних розведень } & \multirow[b]{3}{*}{ 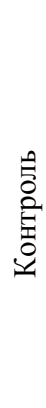 } \\
\hline & \multirow[b]{2}{*}{ 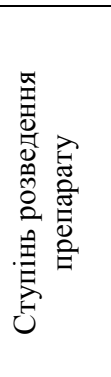 } & \multirow{2}{*}{ 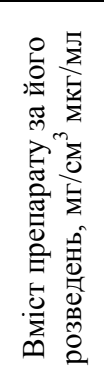 } & \multicolumn{16}{|c|}{ Ріст колоній } & \\
\hline & & & 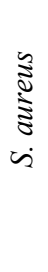 & 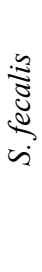 & 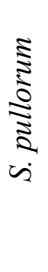 & 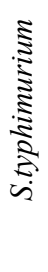 & 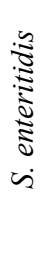 & $\begin{array}{c}\infty \\
0 \\
0 \\
0 \\
0 \\
0\end{array}$ & 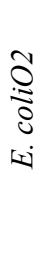 & 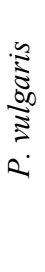 & 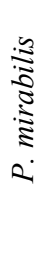 & 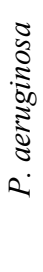 & 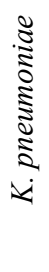 & 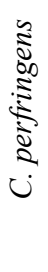 & 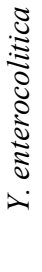 & 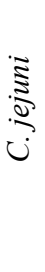 & 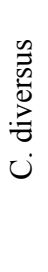 & 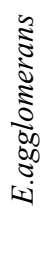 & \\
\hline 1 & - & 1000 & - & - & - & - & - & - & - & - & - & - & - & - & - & - & - & - & + \\
\hline 2 & $1: 2$ & 500 & - & - & - & - & - & - & - & - & - & - & - & - & - & - & - & - & + \\
\hline 3 & $1: 4$ & 250 & - & - & - & - & - & - & - & - & - & - & - & - & - & - & - & - & + \\
\hline 4 & $1: 8$ & 125 & - & - & - & - & - & - & - & - & - & - & - & - & - & - & - & - & + \\
\hline 5 & $1: 16$ & 62,5 & - & - & - & - & - & - & - & - & - & - & - & - & - & - & - & - & + \\
\hline 6 & $1: 32$ & 31,25 & - & - & - & - & - & - & - & - & - & - & - & - & - & - & - & - & + \\
\hline 7 & $1: 64$ & 15,625 & - & - & - & - & - & - & - & - & - & - & - & - & - & - & - & - & + \\
\hline 8 & $1: 128$ & 7,812 & - & - & - & - & - & - & - & - & - & - & - & - & - & - & - & - & + \\
\hline 9 & $1: 256$ & 3,905 & - & - & - & - & - & - & - & - & - & - & - & - & - & - & - & - & + \\
\hline 10 & $1: 512$ & 1,952 & - & - & - & - & - & - & - & - & - & - & - & - & - & - & - & - & + \\
\hline 11 & $1: 1024$ & 0,976 & - & - & - & - & - & - & - & - & - & - & - & - & - & - & - & - & + \\
\hline 12 & $1: 2048$ & 0,488 & - & - & - & - & - & - & - & - & - & - & - & - & - & - & - & - & + \\
\hline 13 & $1: 4096$ & 0,244 & - & - & - & + & - & + & + & + & + & + & + & + & + & + & + & + & + \\
\hline 14 & $1: 8192$ & 0,122 & + & + & + & + & + & + & + & + & + & + & + & + & + & + & + & + & + \\
\hline
\end{tabular}

Примітка: «+»- видимий ріст бактерій; «-»- відсутність видимого росту бактерій 
Результати визначення мінімальної інгібуючої концентрації препарату 10\% енрофлоксацин

\begin{tabular}{|c|c|c|c|c|c|c|c|c|c|c|c|c|c|c|c|c|c|c|c|}
\hline \multirow[b]{3}{*}{ 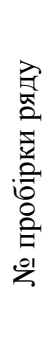 } & \multicolumn{18}{|c|}{ Метод серійних розведень } & \multirow[b]{3}{*}{ 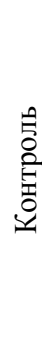 } \\
\hline & \multirow[b]{2}{*}{ 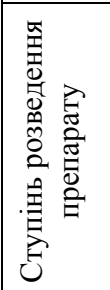 } & \multirow[b]{2}{*}{ 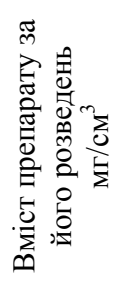 } & \multicolumn{16}{|c|}{ Ріст колоній } & \\
\hline & & & 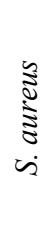 & 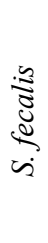 & 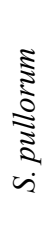 & 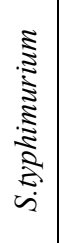 & 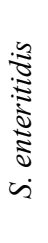 & 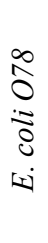 & 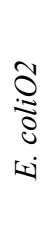 & 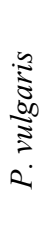 & 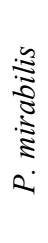 & 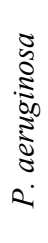 & 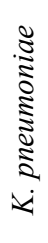 & 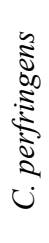 & 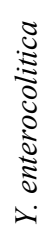 & 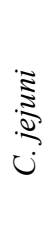 & 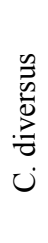 & 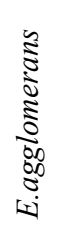 & \\
\hline 1 & - & 1000 & - & - & - & - & - & - & - & - & - & - & - & - & - & - & - & - & + \\
\hline 2 & $1: 2$ & 500 & - & - & - & - & - & - & - & - & - & - & - & - & - & - & - & - & + \\
\hline 3 & $1: 4$ & 250 & - & - & - & - & - & - & - & - & - & - & - & - & - & - & - & - & + \\
\hline 4 & $1: 8$ & 125 & - & - & - & - & - & - & - & - & - & - & - & - & - & - & - & - & + \\
\hline 5 & $1: 16$ & 62,5 & - & - & - & - & - & - & - & - & - & - & - & - & - & - & - & - & + \\
\hline 6 & $1: 32$ & 31,25 & - & - & - & - & - & - & - & - & - & - & - & - & - & - & - & - & + \\
\hline 7 & $1: 64$ & 15,625 & - & - & - & - & - & - & - & - & - & - & - & - & - & - & - & - & + \\
\hline 8 & $1: 128$ & 7,812 & - & - & - & - & - & - & - & - & - & - & - & - & - & - & - & - & + \\
\hline 9 & $1: 256$ & 3,905 & - & - & - & - & - & - & - & - & - & - & - & - & - & - & - & - & + \\
\hline 10 & $1: 512$ & 1,952 & - & - & - & - & - & - & - & - & - & - & - & - & - & - & - & - & + \\
\hline 11 & $1: 1024$ & 0,976 & - & - & - & - & - & - & - & - & - & - & - & - & - & - & - & - & + \\
\hline 12 & $1: 2048$ & 0,488 & + & + & - & + & + & + & - & + & + & + & + & + & - & + & + & + & + \\
\hline 13 & $1: 4096$ & 0,244 & + & + & + & + & + & + & + & + & + & + & + & + & + & + & + & + & + \\
\hline 14 & $1: 8192$ & 0,122 & + & + & + & + & + & + & + & + & + & + & + & + & + & + & + & + & + \\
\hline
\end{tabular}

Таблиия 3

Результати визначення мінімальної інгібуючої концентрації 10\% «Сарофлоксу» та 10\% енрофлоксацину

\begin{tabular}{|c|c|c|c|c|c|}
\hline \multirow{2}{*}{ Ріст колоній м/о } & \multicolumn{2}{|c|}{$\begin{array}{c}10 \% \text { «Сарофлокс» } \\
\text { (дослід) }\end{array}$} & \multicolumn{2}{|c|}{$\begin{array}{c}10 \% \text { енрофлоксацин } \\
\text { (контроль) }\end{array}$} & \multirow{2}{*}{$\begin{array}{c}\text { Активність мінімальної } \\
\text { інгібуючої концентрації } \\
\text { порівняно з контролем } \\
\text { (раз) }\end{array}$} \\
\hline & $\begin{array}{c}\text { ступінь } \\
\text { розведення }\end{array}$ & 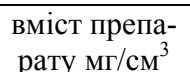 & $\begin{array}{c}\text { ступінь } \\
\text { розведення }\end{array}$ & $\begin{array}{c}\text { вміст препарату } \\
\mathrm{M \Gamma} / \mathrm{cm}^{3}\end{array}$ & \\
\hline S. aureus & $1: 4096$ & 0,244 & $1: 1024$ & 0,976 & 4 \\
\hline S. fecalis & $1: 4096$ & 0,244 & $1: 1024$ & 0,976 & 4 \\
\hline S. pullorum & 1:4096 & 0,244 & $1: 2048$ & 0,488 & 2 \\
\hline S. typhimurium & $1: 2048$ & 0,488 & $1: 1024$ & 0,976 & 2 \\
\hline S. enteritidis & $1: 4096$ & 0,244 & $1: 1024$ & 0,976 & 4 \\
\hline E. coli 078 & $1: 2048$ & 0,488 & $1: 1024$ & 0,976 & 2 \\
\hline E. coli $O 2$ & $1: 2048$ & 0,488 & $1: 2048$ & 0,488 & 0 \\
\hline P. vulgaris & $1: 2048$ & 0,488 & $1: 1024$ & 0,976 & 2 \\
\hline P. mirabilis & $1: 2048$ & 0,488 & $1: 1024$ & 0,976 & 2 \\
\hline P. aeruginosa & $1: 2048$ & 0,488 & $1: 1024$ & 0,976 & 2 \\
\hline K. pneumoniae & $1: 2048$ & 0,488 & $1: 1024$ & 0,976 & 2 \\
\hline C. perfringens & $1: 2048$ & 0,488 & $1: 1024$ & 0,976 & 2 \\
\hline Y. enterocolitica & $1: 2048$ & 0,488 & $1: 2048$ & 0,488 & 0 \\
\hline C. jejuni & $1: 2048$ & 0,488 & $1: 1024$ & 0,976 & 2 \\
\hline C. diversus & $1: 2048$ & 0,488 & $1: 1024$ & 0,976 & 2 \\
\hline E. agglomerans & $1: 2048$ & 0,488 & $1: 1024$ & 0,976 & 2 \\
\hline
\end{tabular}

В результаті аналізу ефективності досліджуваних препаратів визначено, що мінімальна інгібуюча концентраця «Сарофлоксу» порівняно 3 контролем (енрофлоксацином) була вищою в 2-4 рази.

Таким чином, результати наших досліджень вказують на те, що препарат «Сарофлокс» може бути предметом вибору при асоційованих інфекціях птиці 3 причини вищої активності порівняно 3 контрольним засобом на прикладі енрофлоксацину.

\section{Висновки}

Препарат «Сарофлокс» є ефективним відносно до збудників бактеріозів птиці, які найчастіше виділя- ються 3 птахопідприємств України. Бактерицидна активність «Сарофлоксу» є вищою в 2-4 рази порівняно 3 енрофлоксацином. Для більшості бактеріальних культур мінімальна інгібуюча концентрація «Сарофлоксу» становить $0,49 \mathrm{Mг} / \mathrm{cm}^{3}$. Енрофлоксацин проявляє бактерицидну активність переважно у концентрації в $0,98 \mathrm{мг} / \mathrm{cm}^{3}$.

Перспективи подальших досліджень. Вивчення ефективності препарату «Сарофлокс» у виробничих умовах. Дослідження активності засобу порівняно 3 класичними препаратами в умовах птахівничих господарств України. 


\section{Бібліографічні посилання}

Opredeleniye chuvstvitel'nosti mikroorganizmov k antibakterial'nymi preparatami (2004). Metodicheskiye ukazaniya. MUK 4.2.1890-04. Utv. 04.03. 2004. Klinichskaya mikrobiologiya. Antimikrobnaya terapiya. 6(4), 306-359 (in Russian).

Pavlov, E.G., Pavlova, Yu.I., Ayshpur, O.E. (2003). Deyaki bakterial'ni infektsii ta ïh perebig. Ptahivnitstvo. 53, 609-610 (in Ukrainian).
Fotina, A.A. (2013). Novyj preparat dlja profilaktiki boleznej ptic. Innovacii kak faktor razvitija APK i sel'skih territorij: Sborn. mezhdun. nauch-prakt. konf. Smolensk. 2, 394-399 (in Russian).

Fotina, T.I., Sahats'ka, O.I., Stepanischenko, M.M. (2003). Efektivnist' zastosuvannya ekologichnih ta veterinarnih zahodiv pri virobnitstvi produktsiï ptahivnitstva. Ptahivnitstvo. 53, 652-657 (in Ukrainian).

Стаття надійшла до редакиії 30.03.2017 